\title{
Characteristics of interface corrugations in short-period GaAs/AlAs superlattices
}

\author{
L. Daweritz, H. Grahn, R. Hey, B. Jenichen, and K. Ploog \\ Paul-Drude-Institut fur Festkorperelektronik, Hausvogteinplatz 5-7, D-10117 Berlin, Germany \\ D. Korbutyak, S. Krylyuk, Yu. Kryuchenko, and V. Litovchenko \\ Institute of Semiconductor Physics, NAS Ukraine, 45 prospekt Nauki, Kyiv, 252028, Ukraine, \\ tel./fax: +(380-44)2656391,E-mail: korbutyak@div47.semicond.kiev.ua
}

\begin{abstract}
GaAs/AlAs supelattices with corrugated interfaces have been investigated by the polarized photoluminescence method. Using the theoretical approach, which associates the linear polarization of exciton photoluminescence with the corrugation parameters, experimental results have been fitted to determine the height and lateral extension of corrugations.
\end{abstract}

Keywords: Superlattice, Corrugation, Polarization, Photoluminescence.

Paper received 11.06.98; revised manuscript received 29.07.98; accepted for publication 28.10.98.

\section{Introduction}

Recently, investigations of superlattices (SLs) with corrugated interfaces have attracted a substantial attention. It is connected with a possibility to grow directly these structures by the molecular beam epitaxy or the metalorganic chemical vapour deposition methods. Corrugated SLs may be utilized to fabricate 1 - and 0 -dimensional quantum structures, i. e. quantum wires and quantum dots, and to develop different optical and electronic devices such as laser diodes and fast transistors. [1, 2, 3] Therefore, knowledge of the properties of short-period corrugated SLs, in particular, parameters of the corrugation, is very important.

In our previous works it was demonstrated that linear polarization of the exciton photoluminescence (PL) is very sensitive to the presence of a microrelief at the interfaces $[4,5]$. In this case, a substantial PL polarization depending on the corrugation parameters is observed even at zero angle of PL detection. On the other hand, the X-ray diffraction method is widely used to determine the interface roughness. Thus, a combination of these two methods might be a powerful tool for reliable determination of the relief parameters.

\section{Experimental techniques}

We have studied $(\mathrm{GaAs})_{\mathrm{n}} /(\mathrm{AlAs})_{\mathrm{m}}$ SLs grown by the molecular beam epitaxy, where $n$ and $m$ are quantum well and barrier thickness, respectively, expressed in monolayers $(1$ monolayer $=0.283 \mathrm{~nm})$. The parameters of the SLs are summarised in Table I. In the future the samples will be denoted as $n / m$.

The samples may be divided into two groups. In the first one, a microrelief at the interfaces was not created intentionally, but it appeared during a conventional growth procedure and, therefore, had a random distribution. The SLs $36 / 36$ and 4/4 belong to this group. The SLs of second group

Table 1. Parameters of the samples under study

\begin{tabular}{ccccc}
\hline \hline $\begin{array}{c}\text { Number } \\
\text { of sample }\end{array}$ & $\begin{array}{c}\text { Denota- } \\
\text { tion }\end{array}$ & $\begin{array}{c}\text { QW } \\
\text { width, } \\
\text { monolay- } \\
\text { ers }\end{array}$ & $\begin{array}{c}\text { Barrier } \\
\text { width, } \\
\text { mono- } \\
\text { layers }\end{array}$ & $\begin{array}{c}\text { Substrate } \\
\text { orienta- } \\
\text { tion }\end{array}$ \\
\hline 41301 & $36 / 36$ & 36 & 36 & $(100)$ \\
9215 & $4 / 4$ & 4 & 4 & $(100)$ \\
$\begin{array}{c}\text { M4.567 } \\
\left(0^{\circ}\right)\end{array}$ & $14 / 7\left(0^{\circ}\right)$ & 14 & 7 & $(100)$ \\
$\begin{array}{c}\text { M4.567 } \\
\left(2^{\circ}\right)\end{array}$ & $14 / 7\left(2^{\circ}\right)$ & 14 & 7 & $(100)+2^{\circ}$ \\
$\begin{array}{c}\text { M4.567 } \\
(311) \mathrm{A}\end{array}$ & $\begin{array}{c}14 / 7 \\
(311) \mathrm{A}\end{array}$ & 14 & 7 & $(311) \mathrm{A}$ \\
\hline \hline
\end{tabular}




\section{Daweritz et al.: Characteristics of interface corrugations...}

were grown either on the (100) GaAs substrates misoriented toward $<011>$ by $2^{\circ}$ or on the (311)A GaAs substrate. In this case, well-ordered monolayer-height steps or arrays, respectively, appear at the interfaces $[1,6,7]$. The same type of sample grown on the exactly oriented (100) GaAs substrate was used for a comparison. The thickness of quantum wells and barriers in these SLs was 14 and 7 monolayers, respectively.

$\mathrm{PL}$ at $4.2 \mathrm{~K}$ was photoexcited by the $488 \mathrm{~nm}$ line of an $\mathrm{Ar}^{+}$-laser. The laser power was $20 \mathrm{~mW}$. PL radiation was dispersed by a monochromator with the 1200 lines $/ \mathrm{mm}$ grating. The spectral resolution was $0.1 \mathrm{meV}$. PL signal was registered by a cooling photomultiplier and processed by a computer. The experimental system allows PL measurements at different angles of detection $(\theta)$ and when the sample is rotated around the axis normal to its surface (azimuth angle $\varphi)$. The degree of linear polarization of exciton PL was determined as the ratio of the difference to the sum of intensities of PL polarized in the plane of detection and normal to it, respectively.

The samples were also characterized by measurements of grazing incidence X-ray reflectivity and large angle, high resolution diffractometric measurements using a diffractometer (BEDE D3) equipped with two asymmetrically cut grooved silicon crystals in $(n,+n)$ setting $[8,9]$ as a monochromator. The angular divergence behind the monochromator was $0.003^{\circ}$ and the angular acceptance of the detector was below $0.1^{\circ}$. X-ray $\mathrm{CuK} \alpha$ radiation $(\lambda=$ $=0.154 \mathrm{~nm}$ ) from a rotating anode source (operated at $9 \mathrm{~kW}$ ) was used. The high angle diffraction curves were measured in the symmetric (004) and (002) reflection.

\section{Theory}

In order to estimate the relief parameters by measurements of the PL polarization we used the theoretical approach developed in our previous works $[4,5]$. The following fourmedium model have been considered: GaAs substrate with the corrugated surface - GaAs/AlAs superlattice with the same corrugation at the interfaces - GaAs cap layer vacuum. To focus our attention on the excitonic polarization due to interface corrugations, we consider the front surface of the sample as a flat one. Otherwise, additional PL polarization may arise. Moreover, we supposed that the waves emitted by excitonic dipoles propagate in the superlattices without refraction at the interfaces.

Considered here is the particular case of straight-line corrugations oriented along a certain direction ( $\mathrm{y}$-axis). Let $\mathrm{z}$-axis be normal to the front surface and $\mathrm{x}$-axis perpendicular to corrugations. Then, the shape of corrugations can be described by the equation $Z_{i}=f(x),<Z_{i}>=0$, where $Z_{i}$ are $z$-coordinates of points lying at interface. Exciton (electronheavy hole) transitions in quantum wells are characterized by the matrix elements of dipole momentum $\mathbf{p}_{\mathrm{n}}(\mathbf{L})(n=1,2$, 3) related to the unit cell at a site $\mathbf{L}$ :

$$
\mathbf{p}_{\mathrm{n}}(\mathbf{L})=\int_{\Omega(\mathbf{L})} a_{L_{c}}^{*}(\mathbf{r}) e \mathbf{r} a_{L_{v}}^{n}(\mathbf{r}) d^{3} r,
$$

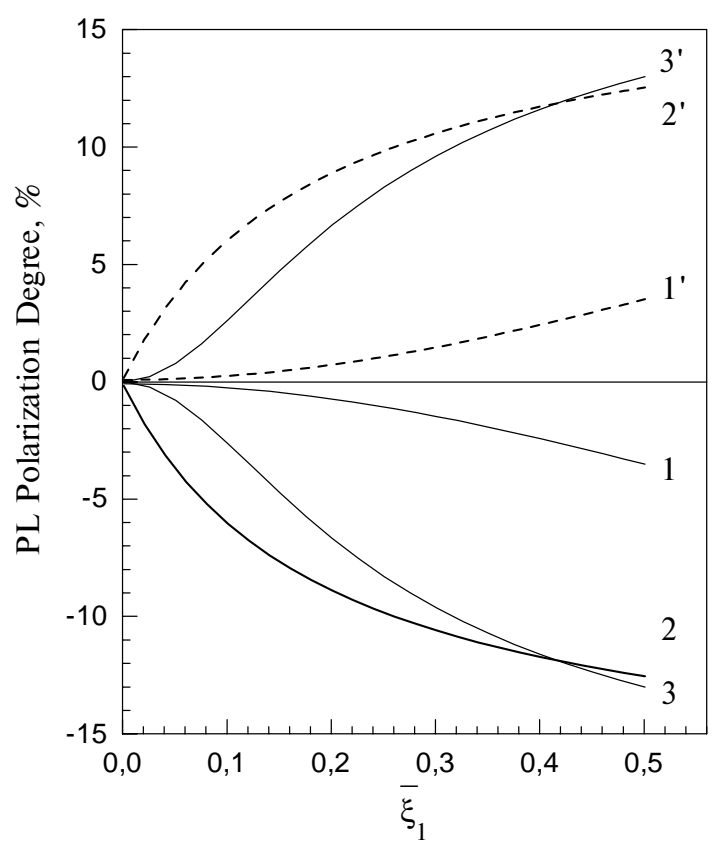

Fig. 1. Comparison of the linear polarization degree for different types of corrugations (symmetrical ones: curves 1 and 1'; asymmetrical ones: curves 2 and 2'; sinusoidal corrugations: curves 3 and $3^{\prime}$ for the detection angle $\theta=0^{\circ}$ and azimuth $\varphi=0^{\circ}$ (solid curves) and $\varphi=90^{\circ}$ (dashed curves); $\Delta \xi_{1}=\Delta \xi_{2}=0.2$. For asymmetrical case, the parameters of sharp slopes are $\xi_{2}=-1$ and $\Delta \xi_{2}=3$.

where $a_{L_{c}}(\mathbf{r})$ is the Wannier function of the conduction band originated from s-states and $a_{L_{v}}^{n}(\mathbf{r})$ are the analogous functions of the valence band originated from three different p-states.

These dipoles are mutually perpendicular vectors. In the absence of corrugations, both modules and orientations of $\mathbf{p}_{\mathrm{n}}$ are independent on $\mathbf{L}$ over the whole quantum well region. In the presence of a smooth relief at the interfaces, the modules of these dipoles are still independent on the coordinate, but their local orientations are determined by those of quantum well layers. If the amplitude of corrugations increases, then additional polarization of PL may arise due to changes in $\mathbf{p}_{\mathrm{n}}$ modulus. For the system under consideration $\mathrm{p}_{1}=\mathrm{p}_{2} \neq \mathrm{p}_{3}$; dipoles $\mathbf{p}_{1}$ and $\mathbf{p}_{2}$ are locally parallel to the interfaces (for simplicity we may choose $\mathbf{p}_{2}$ parallel to y-axis; in this case, it does not depend on coordinate $x$ ), while $\mathbf{p}_{3}$ is locally perpendicular to the interfaces. Thus, orientations of $\mathbf{p}_{1}$ and $\mathbf{p}_{3}$ dipoles are varying with $\mathrm{x}$-coordinate in accordance with local orientations of the quantum wells. As a result, the following formulas for $x$ - and $z$-components of these dipoles can be easily obtained:

$\mathrm{p}_{1, \mathrm{x}}=\mathrm{p}_{1}\left(1+\xi^{2}\right)^{-1 / 2} ; \quad \mathrm{p}_{1, \mathrm{z}}=\mathrm{p}_{1} \xi\left(1+\xi^{2}\right)^{-1 / 2}$

$\mathrm{p}_{3, \mathrm{x}}=\mathrm{p}_{3} \xi\left(1+\xi^{2}\right)^{-1 / 2} ; \quad \mathrm{p}_{3, \mathrm{z}}=\mathrm{p}_{3}\left(1+\xi^{2}\right)^{-1 / 2}$, where $\xi=d Z_{i} / d x=f^{\prime}(x)$. 


\section{Daweritz et al.: Characteristics of interface corrugations...}

Thus, the degree of linear polarization of excitonic PL depends on the shape of corrugations and their dimensions. We calculated the polarization degree (PD) for three cases of corrugation shapes: symmetrical triangles, asymmetrical triangles, and sinusoidal corrugations. Fig. 1 shows the difference between these three cases. The data were obtained for zero detection angle $(\theta) . \varphi$ is the azimuth angle, i. e. the angle between the $\mathrm{x}$-axis and the projection of the PL propagation direction onto the surface. For each case, the distribution of corrugations was characterized by the Gaussian with parameters $\xi_{1}$ and $\xi_{2}$ which the most probable values in the relief for two slopes, while $\Delta \xi_{1}$ and $\Delta \xi_{2}$ are their rootmean-square dispersions, respectively. For symmetrical corrugations, $\xi_{1}=\xi_{2}$ and $\Delta \xi_{1}=\Delta \xi_{2}$. At increasing detection angle PD increases according to conventional polarization effect for the electromagnetic waves transmitted through the front surface into vacuum.

As one can see from fig. 1, the most drastical difference between the considered shapes of corrugations takes place for small values of $\xi$, i. e. for small height-to-length ratio of

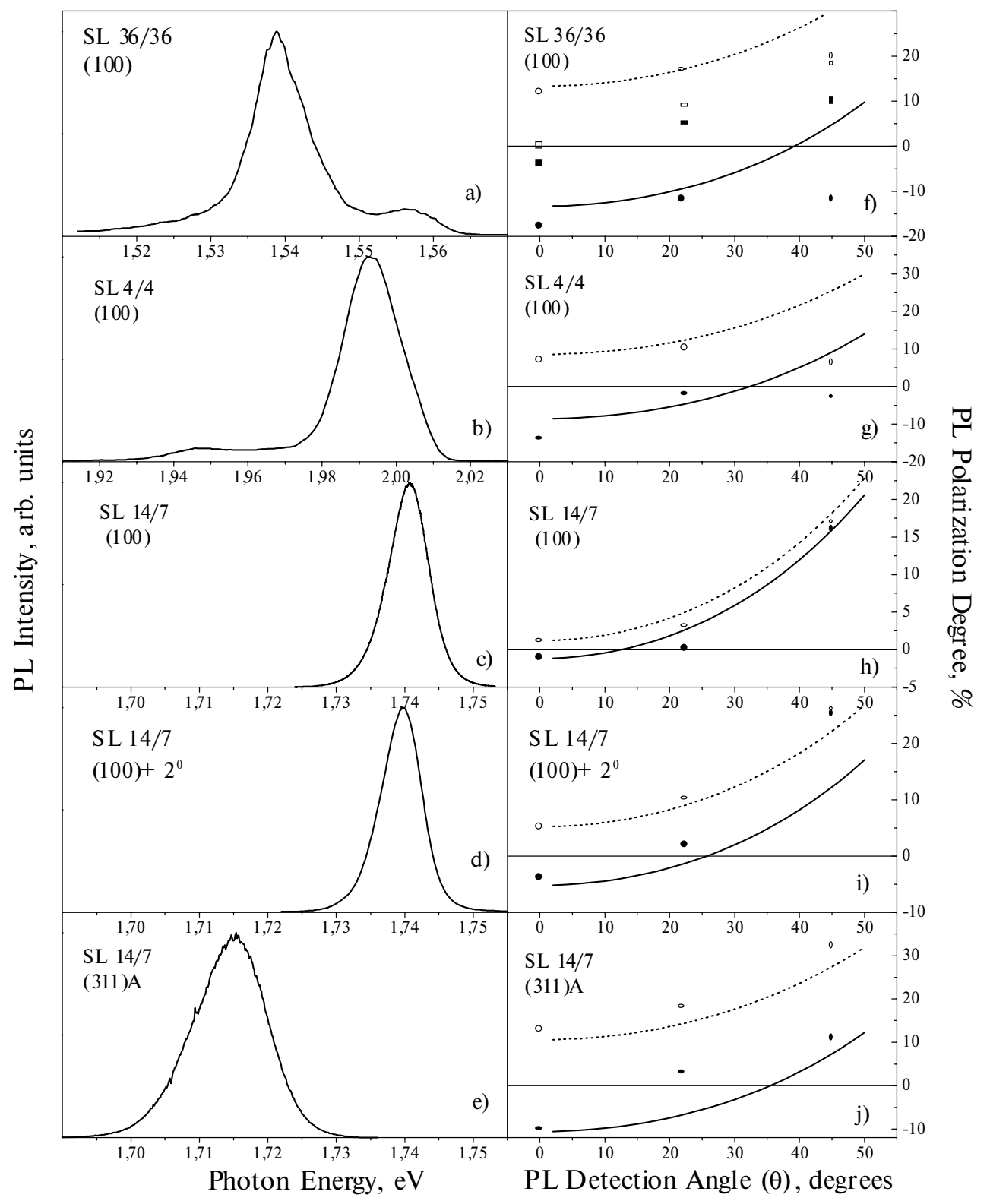

Fig. 2. (a-e): The PL spectra at $5 \mathrm{~K}$ of the SLs under study (f-j): Linear polarization degree versus the PL detection angle. Solid symbols correspond to $\varphi=0^{\circ}$, while open ones to $\varphi=90^{\circ}$. Solid and dashed lines are the fitted curves for $\varphi=0^{\circ}$ and $\varphi=90^{\circ}$, respectively. For the $36 / 36$ SL, circles correspond to polarization of heavy excitons, while squares - to that of light excitons. 


\section{Daweritz et al.: Characteristics of interface corrugations...}

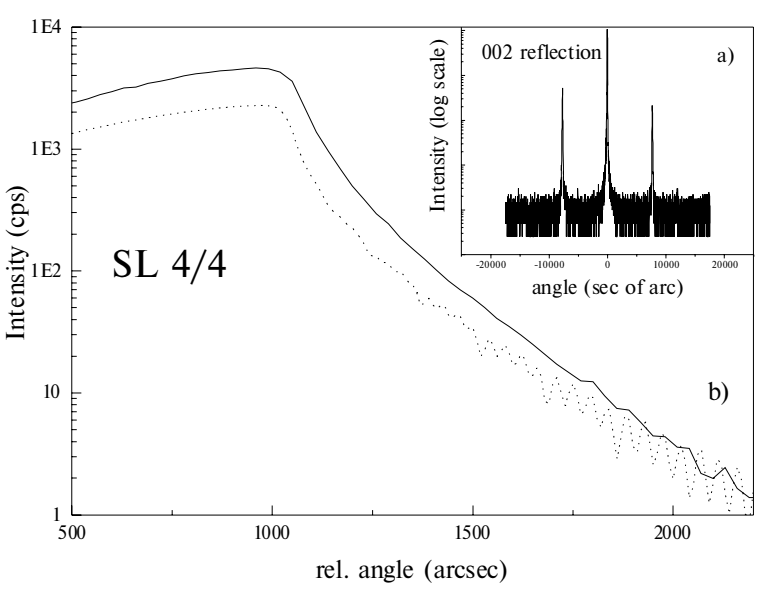

Fig. 3. a) X-ray diffraction curve (near the 002 reflection) for the 4.4 SL; b) comparison of the measured X-ray reflectivity curve of the 4/4 SL with the calculated one. The interference pattern was not observed, probably due to the curvature of the sample. Nevertheless, it seems possible to estimate the surface roughness about $2 \mathrm{~nm}$.

the corrugation dimensions, while for highly corrugated interfaces the difference vanishes.

Thus, by measuring the angular dependence of polarization with subsequent fitting of the curves obtained we can estimate the ratio of the corrugations height to their length.

\section{Experimental results and discussion}

\section{A. Superlattices with a random distribution of corrugations}

A PL spectrum of the SL $36 / 36$ consists of two lines at $1.541 \mathrm{eV}$ and $1.555 \mathrm{eV}$, which are caused by heavy- and light excitons, respectively (fig. 2(a)) [10]. Polarization of the heavy excitons line is very high even at $\theta=0^{\circ}$ $(\mathrm{P}=12-15 \%)$ and increases as $\theta$ rises (fig. 2(f)). At the same time, the line of light excitons exhibits a smaller degree of polarization (fig. 2(f)) in accordance with the isotropic structure of the light-hole subband. We fitted the experimental curves using asymmetrical corrugations model with the following parameters: $\xi_{1}=0.4$ and $\xi_{2}=-4$. The deviation of the experimental curves from the calculated ones is connected with a more complicated shape of the microrelief, i. e. there are regions of the corrugations having different orientation.

Another sample with a random corrugation distribution was SL 4/4. The main line in the PL spectrum of this SL is caused by recombination of the quasi-direct excitons consisting of $X_{z}$-electrons of AlAs and $\Gamma$-heavy holes of GaAs (fig. 2(b)). The two weak bands at the low-energy side of the spectrum correspond to phonon replicas of the main line. The degree of polarization at $\theta=0^{\circ}$ is rather high $(P=$
$=7-15 \%$ ) (fig. $2(\mathrm{~g}))$. It implies large corrugations at the interfaces. The value of $\xi_{1}$ in this case was found to be about 0.3 , while $\xi_{2}=-2$. However, the polarization degree becomes even lower at higher detection angles. It is opposite to what should be expected. Such an anomalous behavior might be caused not only by the nonuniformity of the corrugations, but also by the peculiarities of exciton localization at the interfaces. In this case, the local polarization might be determined by disturbed chemical bonds of surface defects, dislocations, etc. Thus, we can observe a different angular dependence of the polarization degree. However, a theoretical approach should be developed for this case.

Nevertheless, we are able to estimate the corrugation parameters. The lower limit of the lateral extension of the corrugations length is equal to the exciton diameter, $i$. e. $\sim 8-10 \mathrm{~nm}$ in such structures. Hence, the corrugation height is about $2.4-3 \mathrm{~nm}$.

$\mathrm{X}$-ray measurements in the $(002)$ reflection on the SL $4 / 4$ showed clearly pronounced satellite reflections with a peak broadening for the first order reflection below 60 arcsec, indicating a nearly perfect superlattice structure of this sample (fig. 3(a)). By a comparison of the measured X-ray reflectivity curve with simulations $[11,12]$ using the REFS of BEDE program, it is possible to estimate the surface roughness which corresponds to that of the interfaces. The experimental and simulated curves are plotted in fig. 3(b) by solid and dotted lines, respectively. The interference pattern was not observed, probably due to a curvature of the sample. Nevertheless, it seems possible to estimate the surface roughness as about $2 \mathrm{~nm}$.

\section{B. Superlattice with intentionally qrown interface corrugations.}

Low-temperature PL spectra of three 14/7 SLs are plotted in fig. 2(c-e). The experimental and calculated angular dependences of the polarization degree for the SLs with intentionally grown microrelief at the interfaces demonstrate a good qualitative agreement. First of all, excitonic PL in the SL 14/7 grown on the exactly oriented (100) substrates exhibits a very weak polarization at zero detection angle (fig. 2(h)). It implies very smooth interfaces is this sample. For the SL grown on the (100) GaAs substrate misoriented by $2^{\circ}$ towards $\langle 110\rangle$, a higher PL polarization is observed (fig. 2(i)). It is known that well-ordered monolayer-height terraces are formed on such substrates [6]. The lateral extension of these terraces was estimated to be $8.0 \mathrm{~nm}$. The fitting curves were obtained using the values $\xi_{1}=0.04$ and $\xi_{2}=-10$. One can see that the value of $\xi_{1}$ corresponds to the ratio of the height to the length of the terraces estimated independently.

The SLs grown on the (311)A substrate exhibit even larger polarization at $\theta=0^{\circ}$ (fig. 2(j)). In this case, for theoretical description of the relief we have chosen the sinusoidal shape. It is very close to the corrugation shape observed for such SLs [6]. The calculated value of $\xi$ is 0.3 , which agrees well with the corrugation height of $1.02 \mathrm{~nm}$ and the length of $3.2 \mathrm{~nm}$. 


\title{
L. Daweritz et al.: Characteristics of interface corrugations...
}

\section{Conclusions}

1. PL polarization measured at zero detection angle indicates existence of corrugations at the interfaces of SL. If these corrugations are sufficiently regular, i. e. have a small scattering of their geometric parameters (height, length, periodicity, orientation), the quantitative agreement of theory and experiment may be obtained, and the relief parameters may be estimated with a good reliability.

2 . In the case of inhomogeneous corrugations (spot-kind reorientation, high deviation of the linear relief parameters from the average value, etc.), there is a large discrepancy between the theory and experiment, and even a nonmonotonic behavior of the polarization dependences may be observed. For this case, only rough estimations of the corrugations can be made, and a theory for statistical nonmonotonic distribution of corrugations should be developed.

\section{Acknowledgements}

This work was supported by a NATO Linkage Grant and by the Ukrainian Committee for Science and Technology.
References

1. III-V Quantum System Research, ed. by K.H.Ploog, The Institution of Electrical Engineers, 1995.

2. E. Kapon, D. M. Wang, and R. Bhat, Phys. Rev. Lett., 63, p. 430 (1989).

3. M. Kohl, D. Heitmann, P. Grambow, and K. Ploog, Phys. Rev. Lett., 63, p. 2124 (1989).

4. Litovchenko V. G., Korbutyak D. V., S. G.Krylyuk, Yu. V. Kryuchenko, V. I. Sugakov, H. T. Grahn, and K. Ploog, SPIE Proc., 2648, p. 294 (1995).

5. Litovchenko V. G., Korbutyak D. V., S. G.Krylyuk, Yu. V. Kryuchenko, H. T. Grahn, and K. Ploog, Phys. Low-Dimens. Structures, 10/11, p. 187 (1995).

6. Gainess J. M., Petroff P. M., Kroemer H., Simes R. J., Geels R. S. and English J. H., J. Vac. Sci Technol., B 6, p. 1387 (1988); Fukui T., Saito H., Jpn. J. Appl. Phys., 29, L731 (1990).

7. Notsel R., Daweritz L., and Ploog. K., Phys. Rev., B 46, p. 4736 (1992); Notsel R., Ledentsov N.N., Daweritz L., and Ploog. K., Phys. Rev., B 45, p. 3507 (1992).

8. W. Du Mond, Phys. Rev., 52, p. 827 (1937).

9. W. J. Bartles, J. Vac. Sci. Technol., 1, p. 359 (1983).

10. Litovchenko V. G., Bercha A. I., Korbutyak D. V., Gavrilenko V. I., and Ploog K., Thin Solid Films, 217, p. 62 (1992).

11. L.G.Parratt, Phys. Rev., 95, p. 359 (1954).

12. M. Wormigton, D. K. Bowen, and B. K. Tanner in Structure and properties of interfaces in materials ed. by W.A.T.Clark, U.Dahmen, C.L.Briant (Mat. Res. Soc. Proc. 238, Pittsburh, PA, 1992) pp. 119124.

\section{ХАРАКТЕРИСТИКИ КОРУГОВАНОСТІ ІНТЕРФЕЙСУ В КОРОТКОПЕРІОДНИХ НАДГРАТКАХ GaAs/AІАS}

\author{
Л. Давериц, Х. Гран, Р. Хей, Б. Сніхен, К. Плог \\ Інститут твердотільної електроніки ім. П. Друде, Берлін, Німеччина
}

Д. Корбутяк, С. Крилюк, Ю. Крюченко, В. Літовченко Інститут фізики напівпровідників НАН Украӥни

Резюме. Методом поляризованої фотолюмінесценції досліджені надгратки GaAs/AlAs 3 коругованими гетеромережами. Співставляючи експериментальні результати з теоретичними розрахунками на основі моделі, яка пов'язує ступінь лінійної поляризації екситонної фотолюмінесценції з параметрами коругованостей, визначені висота та латеральна протяжність коругованостей.

\section{ХАРАКТЕРИСТИКИ КОРРУГИРОВАННОСТИ ИНТЕРФЕЙСА В КОРОТКОПЕРИОДНЫХ СВЕРХРЕШЕТКАХ} GaAs/AlAs

\author{
Л. Давериц, Х. Гран, Р. Хей, Б. Енихен, К. Плог \\ Институт твердотельной электроники им. П. Друде, Берлин, Германия
}

Д. Корбутяк, С. Крылюк, Ю. Крюченко, В. Литовченко

Институт физики полупроводников НАН Украины

Резюме. Методом поляризованной фотолюминесценции исследованы сверхрешетки GaAs/AlAs с корругированными гетерограницами. Путем сравнения експериментальных результатов с теоретическими расчетами, базирующимися на модели, которая связывает степень линейной поляризации экситонной фотолюминесценции з параметрами корругованностей, определены высота и латеральная протяженность корругованностей. 